\title{
Interactions Among Sweet potato chlorotic stunt virus and Different Potyviruses and Potyvirus Strains Infecting Sweetpotato in the United States
}

\author{
C. D. Kokkinos and C. A. Clark, Department of Plant Pathology and Crop Physiology, Louisiana Agricultural Ex- \\ periment Station, Louisiana State University Agricultural Center, Baton Rouge 70803
}

\begin{abstract}
Kokkinos, C. D., and Clark, C. A. 2006. Interactions among Sweet potato chlorotic stunt virus and different potyviruses and potyvirus strains infecting sweetpotato in the United States. Plant Dis. 90:1347-1352.

Sweet potato virus disease (SPVD) is the most serious viral disease of sweetpotato globally. This disease is caused by the synergistic interaction between the aphid-transmitted potyvirus Sweet potato feathery mottle virus (SPFMV) and the whitefly-transmitted crinivirus Sweet potato chlorotic stunt virus (SPCSV). In sweetpotato, titers of SPFMV have been shown to be significantly enhanced when co-infecting with SPCSV. In this study, the effect of SPCSV on titers of different potyviruses and potyvirus strains infecting sweetpotato in the United States was investigated using real-time quantitative reverse transcription-polymerase chain reaction (RT-PCR). No significant difference was observed in titers of the russet crack strain of SPFMV (SPFMV$\mathrm{RC}$ ), Ipomoea vein mosaic virus (IVMV), and Sweet potato virus G (SPVG) between single and mixed infections. Titers of all potyviruses and potyvirus strains evaluated were enhanced in the presence of SPCSV, suggesting that a conserved mechanism may underlie these interactions. Titers of the common strain of SPFMV (SPFMV-C), which did not cause SPVD-like symptoms when co-infecting with SPCSV, were also significantly enhanced in the presence of SPCSV. Furthermore, titers of SPCSV were found to be lower in treatments involving pairwise infections compared with plants infected by SPCSV alone. The degree of potyvirus titer enhancement did not correspond to the severity of symptoms observed in certain treatments involving pairwise infections.
\end{abstract}

Sweetpotato is affected by several virus disease complexes. These complexes, reported in different countries around the globe, generally include Sweet potato feathery mottle virus (SPFMV), a member of the genus Potyvirus in the family Potyviridae, as one component (25). Sweet potato virus disease (SPVD), which has been characterized as the major constraint in increasing sweetpotato productivity worldwide $(3,13,25)$, is caused by the synergistic interaction between SPFMV and Sweet potato chlorotic stunt virus (SPCSV), a member of the genus Crinivirus in the family Closteroviridae. Schaefers and Terry (26) first reported that alone, SPFMV and SPCSV induce only very mild symptoms, but the synergistic interaction in dual infections causes the severe symptoms observed in the field. Since then, other viruses such as Sweet potato chlorotic fleck virus (SPCFV),

Corresponding author: C. A. Clark

E-mail: cclark@agctr.lsu.edu

* The $\boldsymbol{e}$-Xtra logo stands for "electronic extra" and indicates the HTML abstract available on-line contains three supplemental figures not included in the print edition.

Accepted for publication 7 June 2006.

DOI: 10.1094/PD-90-1347

(C) 2006 The American Phytopathological Society
Sweet potato latent virus (SPLV), Sweet potato mild speckling virus (SPMSV), and Sweet potato mild mottle virus (SPMMV) have been detected occasionally in sweetpotato plants exhibiting severe SPVD-like symptoms, but these viruses have never been proven to play an important role in this disease complex $(9,11,29)$.

Two potyviruses recently described infecting sweetpotato in the United States, Ipomoea vein mosaic virus (IVMV) and Sweet potato virus $G$ (SPVG) (28), enhanced symptoms in sweetpotato plants when co-infecting with SPCSV. For that reason, IVMV and SPVG have been suspected to contribute to the variation of SPVD-like symptoms observed in naturally infected plants from different geographic locations (S. S. Hurtt, personal communication). Their importance, however, has often been overshadowed by the universal presence of SPFMV, which is found wherever sweetpotatoes are grown (6). Two strains of SPFMV have been recognized in the United States, the common strain (SPFMV-C) and the russet crack strain (SPFMV-RC) (19).

To date, SPVD has been reported in a number of African countries, including Rwanda, Burundi, Uganda, Ghana, Nigeria, Kenya, Tanzania, and Zimbabwe (13), as well as other countries such as Israel (18), Spain (30), and Peru (11). In the United States, SPCSV, one of the two components known to cause SPVD, has only been found in one sweetpotato tissue culture accession but has not been reported from the field (22).

During co-infections of SPFMV with SPCSV, sweetpotato plants exhibit severe symptoms such as leaf strapping, vein clearing, leaf distortion, chlorosis, puckering, and stunting (25). Symptoms on SPVD-affected sweetpotato plants develop first in the newly emerging leaves. In the late 1930s, Stayaert reported that within a few years in the republic of Congo, sweetpotato crops of $30 \mathrm{t} /$ year were reduced to 4 t/year, resulting in their abandonment (27). Since then, several cases of extreme yield loss (up to $90 \%$ ) have been reported from different sweetpotato cultivars affected with SPVD $(11,12,20)$, including Beauregard (4), which is the predominant cultivar in U.S. sweetpotato production. Such dramatic yield reductions are correlated with the severity of leaf stunting and strapping symptoms observed (25).

Karyeija et al. (14) found that the titers of SPFMV were relatively high in all leaf parts in SPVD-affected plants and could be detected both by triple antibody sandwich (TAS) and nitrocellulose membrane (NCM) enzyme-linked immunosorbent assays (ELISA). In contrast, SPFMV in singly infected sweetpotato plants was detected only on rare occasions by any of the test methods utilized. In SPVDaffected plants, SPFMV was not confined to any leaf parts, whereas SPCSV was found only in the veins of the leaves tested. Furthermore, immunohistochemical tests confirmed that SPCSV was phloemlimited (14). Quantification of the two viruses using an RNA dot-blot hybridization method revealed a 600-fold increase of SPFMV RNA in SPVD-affected plants compared with single infections with SPFMV. This led to the hypothesis that SPCSV is able to enhance the multiplication of SPFMV in tissues even though titers of SPCSV remain relatively unchanged (14). Such results are unusual in that potyviruses have been shown to play the role of the "titer enhancer" in other viral complexes $(1,10,31,32)$.

To date, the exact mechanism of synergism between the two viruses that cause SPVD is unknown. In this paper, we report for the first time the use of real-time reverse transcription-polymerase chain reaction (RT-PCR), a sensitive quantitative assay, to study the effect of SPCSV on titers of other potyviruses and potyvirus 
strains infecting sweetpotato. Additionally, three of the most commonly occurring potyviruses in the United States, SPFMVRC, IVMV, and SPVG, were further evaluated for their ability to interact with each other in pairwise and three-way combinations.

\section{MATERIALS AND METHODS}

Plant material and virus inoculations. All virus-tested plants (clonally propagated I. batatas cv. Beauregard plants indexed as free of known viruses by grafting three times to the indicator host, I. setosa) were inoculated by grafting with scions from greenhouse-grown source plants. Scions were from either clonally propagated $I$. batatas plants infected with the nonmechanically transmissible SPCSV isolate BWFT-3 and/or I. setosa seedlings that had previously been mechanically inoculated separately with isolate 95-2 of the russet crack strain of SPFMV (SPFMV-RC), the common strain of SPFMV (SPFMV-C), isolate 95-6 of SPFMV (phylogenetically closest to SPFMV-C), IVMV (isolate LSU-2), and SPVG (isolate LSU-1). The use of $I$. setosa, the standard indicator host for sweetpotato viruses, as the source of scions for potyviruses provided scions with titers comparable to those of SPCSV in scions generated from sweetpotato plants (17). Eleven treatments of six plants were evaluated in a randomized complete block design, consisting of each potyvirus inoculated alone and in pairwise combination with SPCSV. The combinations of SPFMV-RC and SPFMV-C with SPCSV were repeated.

In a separate experiment, scions from $I$. setosa plants mechanically inoculated with SPFMV-RC, IVMV, and SPVG alone were used to graft-inoculate clonally propagated virus-tested Beauregard. In this experiment, seven treatments consisting of each potyvirus inoculated alone and in pairwise and three-way combinations with each other were evaluated in a randomized complete block design. This experiment was conducted twice.
Three weeks after planting, a single wedge graft for each virus was made, and only plants on which the scion(s) survived for at least 3 weeks were used in these studies. All treatments were replicated six times. Plants were grown under standard greenhouse conditions in $15-\mathrm{cm}$-diameter clay pots containing autoclaved soil mix consisting of 1 part river silt, 1 part sand, 1 part Jiffy-Mix Plus (Jiffy Products of America Inc., Norwalk, $\mathrm{OH}$ ) and $3.5 \mathrm{~g}$ per pot of Osmocote 14-14-14 (Scotts-Sierra Horticultural Products Company, Marysville, $\mathrm{OH}$ ). A weekly insecticide spray program was followed to control aphids and whiteflies. At 3, 6, and 9 weeks after inoculation, the first four consecutive fully opened leaves from the top of each test plant were collected, combined, and immediately frozen in liquid nitrogen and stored at $-80^{\circ} \mathrm{C}$ until extraction of total RNA. At each collection date, plants were cut back to an approximate length of five nodes. Because sweetpotato plants infected with any of the potyviruses alone are typically symptomless, nodes randomly selected after the final leaf collection were grafted on I. setosa indicator plants to confirm the presence of the appropriate potyvirus.

Total nucleic acid extractions. Frozen leaf tissue (approximately $70 \mathrm{mg}$ ) was ground to a fine powder in liquid nitrogen using a mortar and pestle, and total RNA and DNA were extracted using Qiagen's RNeasy Plant Mini Kit (Qiagen Inc., Valencia, CA) according to the manufacturer's directions. To eliminate residual DNA contamination, all total RNA samples were treated on-column with DNase I using the RNase-Free DNase Set (Qiagen).

Real-time RT-PCR assays. Real-time RT-PCR assays were performed in 50- $\mu$ l reaction volume mixtures containing 900 $\mathrm{nM}$ of each primer (forward and reverse), $200 \mathrm{nM}$ of the MGB TaqMan probe, 25 or $1.25 \mu \mathrm{l}$ of $2 \times$ or $40 \times$ master mixes, respectively, of the TaqMan One Step PCR Master Mix Reagents kit (Applied Biosystems, Foster City, CA), and $5 \mu \mathrm{l}$ of template RNA (17). The same protocol was fol-

Table 1. Symptoms observed in sweetpotato (cv. Beauregard) plants involving pairwise infections of Sweet potato chlorotic stunt virus (SPCSV) with the russet crack strain of Sweet potato feathery mottle virus (SPFMV-RC), the common strain of SPFMV (SPFMV-C), isolate 95-6 of SPFMV (phylogenetically related to SPFMV-C), Ipomoea vein mosaic virus (IVMV), and Sweet potato virus G (SPVG)

\begin{tabular}{llll}
\hline & \multicolumn{3}{c}{ Symptoms $^{\mathbf{a}}$} \\
\cline { 2 - 4 } Treatment & \multicolumn{1}{c}{$\mathbf{3 ~ W P I}^{\mathbf{b}}$} & \multicolumn{1}{c}{$\mathbf{6}$ WPI } & \multicolumn{1}{c}{$\mathbf{9}$ WPI } \\
\hline SPCSV+SPFMV-RC & CHL, CS, MLD, VB & CHL, LD, MLF, VB & CHL, LD, MLF, VB \\
SPCSV+SPFMV-C & MIP, TVC & MIP, TVC & MIP, TVC \\
SPCSV+SPFMV-95-6 & CHL, CS, MLD, VB & CHL, LD, VB & CHL, LD, VB \\
SPCSV+IVMV & CHL, CS, LD, ST, VM & CHL, LD, VM, VN, & CHL, LD, VM, VN, \\
& & SP, ST & SP, ST \\
SPCSV+SPVG & MCHL, MLD, MVC & CHL, MLD, MVC & CHL, MLD, MVC \\
\hline
\end{tabular}

a Symptom abbreviations: $\mathrm{CHL}=$ general chlorosis, $\mathrm{CS}=$ chlorotic spots, $\mathrm{LD}=$ leaf distortion, $\mathrm{MCHL}$ $=$ mild general chlorosis, $\mathrm{MIP}=$ mild interveinal purpling, $\mathrm{MLD}=$ mild leaf distortion, $\mathrm{MLF}=$ mild leaf fan, $\mathrm{MVC}=$ mild vein clearing, $\mathrm{SP}=$ severe puckering, $\mathrm{ST}=$ stunting, $\mathrm{TVC}=$ transient vein clearing, $\mathrm{VB}=$ vein banding, $\mathrm{VM}=$ vein mosaic, $\mathrm{VN}=$ vein necrosis.

$\mathrm{b}$ WPI = weeks postinoculation. lowed for the endogenous control reactions, which enabled normalization of variation between sample extracts, except for the substitution of the target virus primer/probe set with $2.5 \mu \mathrm{l}$ of the eukaryotic $18 \mathrm{~S}$ rRNA primer/probe mix (VIC/ MGB Probe) (Applied Biosystems). The following real-time RT-PCR thermal cycling conditions were used: $48^{\circ} \mathrm{C}$ for 30 min (cDNA synthesis), $95^{\circ} \mathrm{C}$ for $10 \mathrm{~min}$, followed by 40 cycles of denaturation at $95^{\circ} \mathrm{C}$ for $15 \mathrm{~s}$ and annealing/extension at $60^{\circ} \mathrm{C}$ for $1 \mathrm{~min}$.

All real-time RT-PCR reactions were performed on ABI PRISM 7000 Sequence Detection System using MicroAmp optical 96-well reaction plates that were sealed with optical adhesive covers (Applied Biosystems). The thermalcycling parameters were optimized for use with the TaqMan One Step PCR Master Mix Reagent kits in singleplex reactions (Applied Biosystems). To minimize any errors due to pipetting differences, duplicates of each sample were performed on each plate, and their threshold cycle $(\mathrm{Ct})$ values were averaged during data analysis. In addition, every plate included nontemplate water controls (NTC) as well as positive (total RNA from virus-infected source plants) and negative (total RNA from virus-tested plants) controls. After validation experiments were performed as described in User Bulletin \#2 (Applied Biosystems), the comparative $\mathrm{Ct}$ method $(\Delta \Delta \mathrm{Ct})$ was used to calculate target quantity from $\mathrm{Ct}$ values. This method, which eliminates the use of standard curves on every plate, was implemented for the normalization, relative to the $18 \mathrm{~S}$ rRNA endogenous control, of extraction variation due to minor differences in quantity and quality of tissue used for each sample. The efficiency of amplification of each target virus and the endogenous control were previously shown to be the same by comparing slopes of their respective standard curves (17). Normalized virus titers are not absolute values but values derived from the mathematical formula $N=2^{-\Delta \mathrm{Ct}}$, where $N$ is the normalized value and $\Delta \mathrm{Ct}$ is the difference in $\mathrm{Ct}$ 's between the target virus and the endogenous control. This method is based on uniform efficiency of amplification of the endogenous control and target (virus) in a basis sample (a sample for each particular target virus with sufficient quantities of virus and endogenous control to permit construction of standard curves). Since each virus and endogenous control had the same efficiency of amplification, virus targets were normalized to the same endogenous control, and $\mathrm{Ct}$ values were obtained using the same critical threshold, allowing comparison of titers among viruses. The term titer, which is used throughout this manuscript, indicates amounts of viral RNA rather than amounts of virus particles present in the plant. 


\section{RESULTS}

Virus symptoms. At the time leaf samples were collected, all test plants coinfected with SPCSV and any of the potyviruses SPFMV-RC, SPFMV-95-6, IVMV, and SPVG, but not SPFMV-C, exhibited distinctive foliar symptoms; whereas plants infected only with a single potyvirus were generally asymptomatic (Table 1). Initial symptoms were observed in plants co-infected with SPFMV-RC and SPCSV at approximately 10 days postinoculation (DPI), and included severe chlorotic vein banding, leaf distortion, and fan-leaf, symptoms that are characteristic of SPVD. Plants co-infected with SPFMV-95-6 and SPCSV showed initial symptoms at 12 DPI and eventually developed leaf distortion and chlorotic vein banding. Symptoms on plants co-infected with IVMV and SPCSV occurred at 17 DPI and included severe leaf distortion, vein necrosis, and severe leaf puckering. Plants co-infected with SPVG and SPCSV also developed symptoms at 17 DPI, but exhibited milder vein chlorosis than the other potyvirus/SPCSV combinations. Symptoms in plants co-infected with SPFMV-C and SPCSV were mild, including transient vein clearing and mild interveinal purpling, similar to plants singly infected with SPCSV. Plants infected with any of the potyviruses alone were asymptomatic, as expected (28). Plants infected with SPFMV-RC, IVMV, and SPVG in pairwise and three-way combinations were also asymptomatic.

Quantification of potyviruses alone and in pairwise combination with
SPCSV. At 3, 6, and 9 weeks after inoculation, titers of SPFMV-RC were greater when plants were co-infected with SPCSV ( $P=0.002, P<0.001, P=0.001$, respectively) compared with titers of SPFMV-RC in single infections (Figs. 1A and 2). The same was true for SPFMV-C $(P<0.001, P$ $=0.003, P=0.001)$ (Fig. 1B), SPFMV-95$6(P=0.003, P=0.001, P=0.007)$ (Fig. 1C), $\operatorname{IVMV}(P=0.031, P=0.041, P=$ $0.003)$ (Fig. 1D), and SPVG $(P=0.047, P$ $=0.02, P=0.035)$ (Fig. 1E). In the presence of SPCSV, SPFMV-95-6 had the greatest enhancement of titer of all the potyviruses tested, whereas SPFMV-RC had the least. In singly infected plants, titers of each of the viruses were either very low or below the threshold of detection of the real-time RT-PCR assay (Fig.
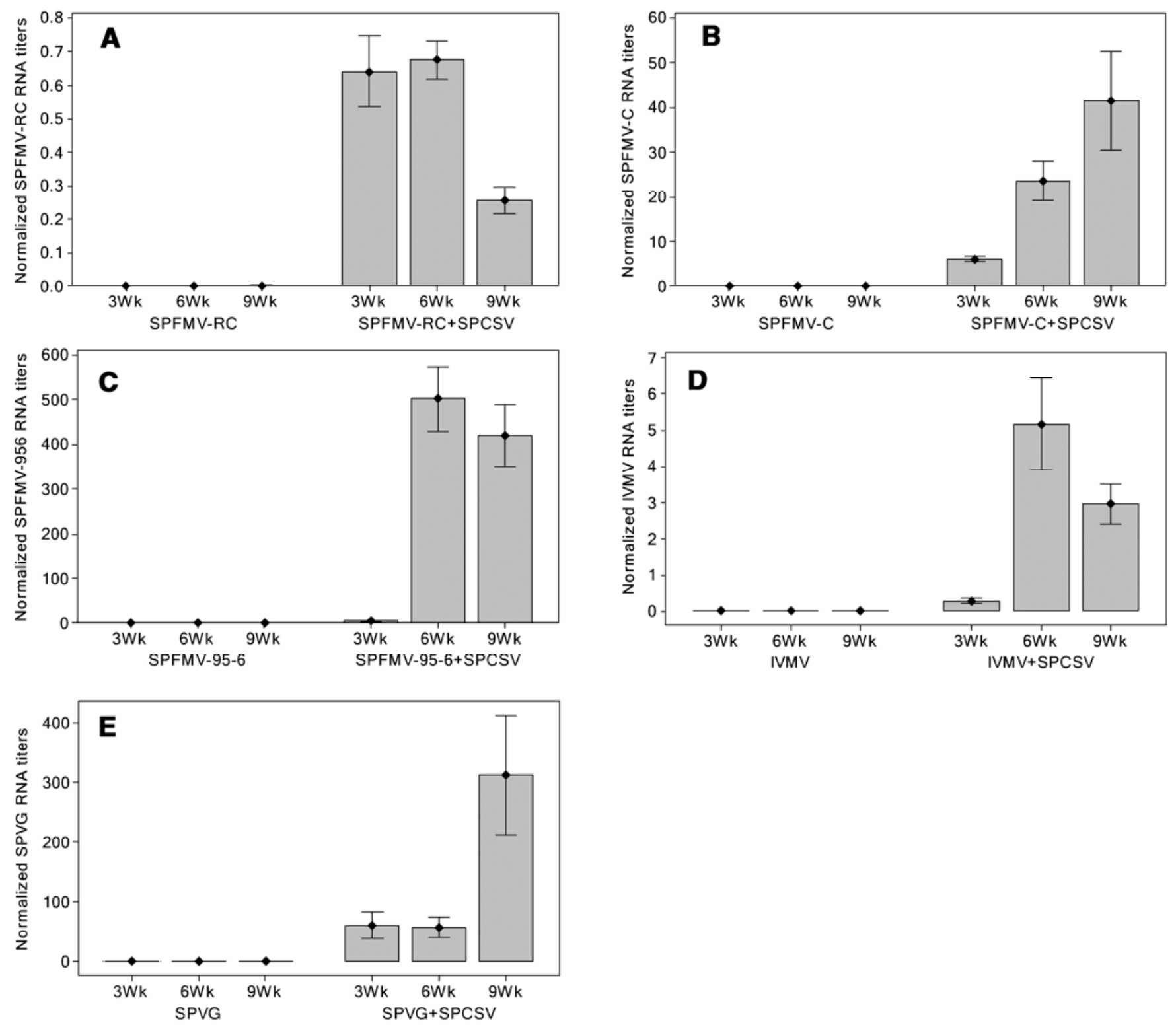

Fig. 1. Mean RNA titers, normalized to an endogenous control (18s rRNA), determined by real-time quantitative reverse transcription-polymerase chain reaction (RT-PCR) in single and pairwise infections with Sweet potato chlorotic stunt virus (SPCSV) of A, the russet crack strain of Sweet potato feathery mottle virus (SPFMV-RC), B, the common strain of SPFMV (SPFMV-C), C, isolate 95-6 of SPFMV (SPFMV-95-6), D, Ipomoea vein mosaic virus (IVMV), and $\mathbf{E}$, Sweet potato virus $G$ (SPVG) at 3, 6, and 9 weeks postinoculation (WPI) in six cv. Beauregard sweetpotato plants. Normalized virus RNA titers ( $N$ ) are derived from the mathematical formula $N=2^{-\Delta \mathrm{Ct}}$, where $\Delta \mathrm{Ct}$ is the difference between the threshold cycles (Ct) of the target virus and endogenous control obtained from their respective real-time amplification plots. Interval bars represent one standard error of the mean. 
2), which is consistent with previous findings $(14,17)$. Quantities of SPFMV-RC, SPFMV-C, and SPCSV were similar when these treatments were repeated. Although virus was sometimes not detected by realtime RT-PCR in single potyvirus infections, virus was recovered from all plants sampled by graft indexing on I. setosa at the conclusion of the experiment.

Quantification of SPCSV. Titers of SPCSV in single infections were significantly greater than titers of the same virus in co-infections with individual potyviruses (Fig. 3$)$ at either 3 weeks $(P=0.001)$ or 6 weeks $(P<0.001)$ after inoculation. Even though at 9 weeks after inoculation, titers of SPCSV in single infections remained significantly greater $(P=0.006)$ than titers of SPCSV in pairwise combinations with SPFMV-RC, IVMV, and SPVG, no significant difference was observed between SPCSV alone and SPCSV in pairwise combinations with SPFMV-C and SPFMV-95-6. No significant difference

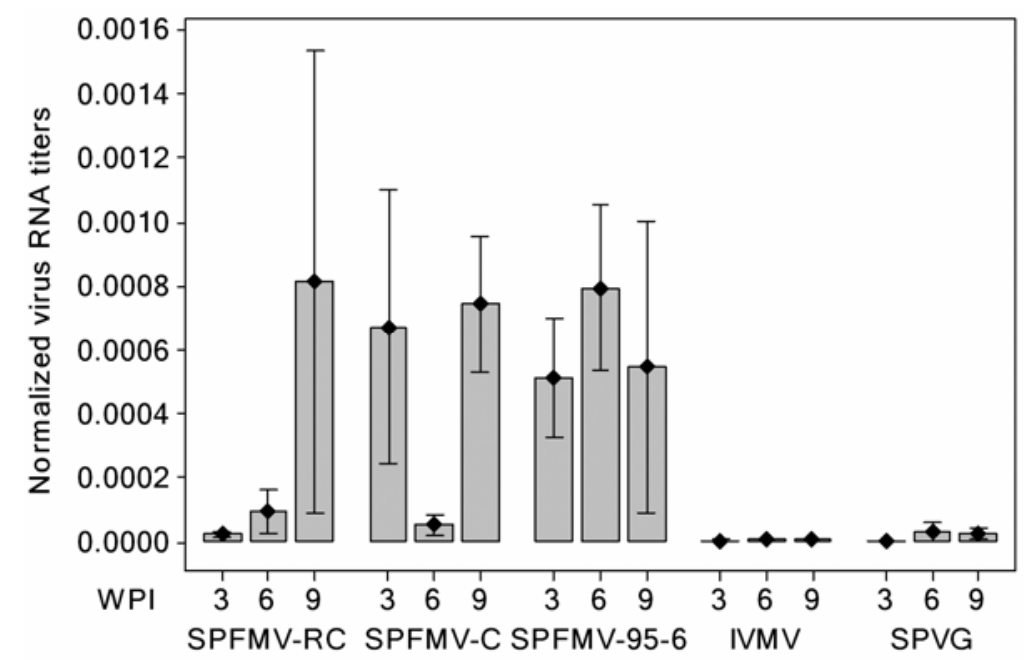

Fig. 2. Mean RNA titers, normalized to an endogenous control (18s rRNA) determined by real-time quantitative reverse transcription-polymerase chain reaction (RT-PCR) of the russet crack strain of Sweet potato feathery mottle virus (SPFMV-RC), the common strain of SPFMV (SPFMV-C), isolate 95-6 of SPFMV (SPFMV-95-6), Ipomoea vein mosaic virus (IVMV), and Sweet potato virus G (SPVG) in six singly infected cv. Beauregard sweetpotato plants at 3, 6, and 9 weeks postinoculation (WPI). Normalized virus RNA titers $(N)$ are derived form the mathematical formula $N=2^{-\Delta \mathrm{C}^{t}}$, where $\Delta \mathrm{Ct}$ is the difference between the threshold cycles $(\mathrm{Ct})$ of the target virus and endogenous control obtained from their respective real-time amplification plots. Interval bars represent one standard error of the mean.

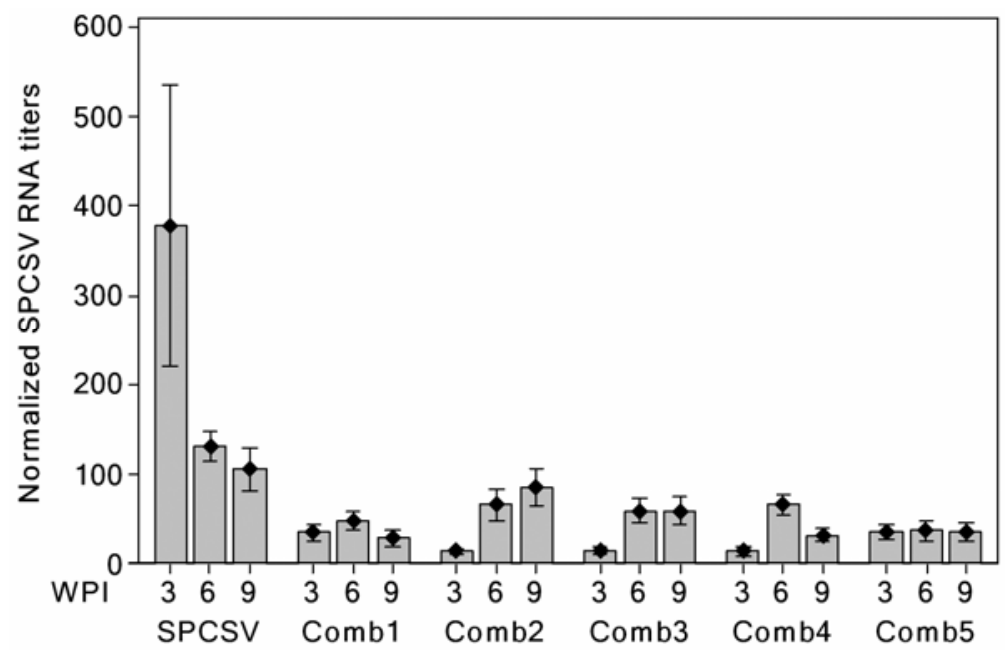

Fig. 3. Mean RNA titers, normalized to an endogenous control (18s rRNA) determined by real-time quantitative reverse transcription-polymerase chain reaction (RT-PCR) of Sweet potato chlorotic stunt virus (SPCSV) in single and pairwise infections with the russet crack strain of Sweet potato feathery mottle virus (SPFMV-RC) (Comb1), the common strain of SPFMV (SPFMV-C) (Comb2), isolate 95-6 of SPFMV (Comb3), Ipomoea vein mosaic virus (IVMV) (Comb4), and Sweet potato virus G (SPVG) (Comb5) at 3, 6, and 9 weeks postinoculation (WPI) in six cv. Beauregard sweetpotato plants. Normalized virus RNA titers $(N)$ are derived form the mathematical formula $N=2^{-\Delta \mathrm{Ct}}$, where $\Delta \mathrm{Ct}$ is the difference between the threshold cycles $(\mathrm{Ct})$ of the target virus and endogenous control obtained from their respective real-time amplification plots. Interval bars represent one standard error of the mean.

was observed in titers of SPCSV among treatments involving pairwise infections. Unlike any of the potyviruses assayed, SPCSV was detected in all singly infected plants, and its titers were significantly greater $(P<0.001)$ compared with those of any potyvirus in single infections at each assessment date.

Quantification of SPFMV-RC, IVMV, and SPVG in pairwise and three-way combinations. Titers of SPFMV-RC, IVMV, and SPVG were either very low or below the threshold of detection regardless of whether they were infecting alone or as a mixture with other potyviruses. No significant difference was observed in titers of SPFMV-RC at 3 weeks $(P=0.47), 6$ weeks $(P=0.43)$, and 9 weeks $(P=0.50)$ postinoculation (Fig. 4A), or for IVMV ( $P$ $=0.15, P=0.59, P=0.60)$ (Fig. 4B), or SPVG $(P=0.16, P=0.18, P=0.09)$ (Fig $4 C)$. The results presented are from one run of this experiment, and results of the second experiment were very similar.

\section{DISCUSSION}

SPVD, the most economically important viral disease of sweetpotato, is caused by the synergistic interaction between SPFMV and SPCSV. Many cultivars, including Beauregard, the predominant cultivar grown in the United States, are highly susceptible to SPVD with reported yield losses as great as $90 \%(4,11,12,20)$. Other potyviruses such as IVMV and SPVG, which when co-infecting with SPCSV also cause severe symptoms, may play an important role in the type and severity of symptoms observed in naturally infected plants (S. S. Hurtt, personal communication). In this study, titers of all potyviruses evaluated were significantly enhanced in the presence of SPCSV, suggesting the existence of a common mechanism underlying the enhancement of potyvirus replication. However, the degree of titer enhancement did not correspond to the symptoms observed. This was true even among the two strains of SPFMV. Although titers of SPFMV-C were enhanced more than titers of SPFMV-RC or IVMV in the presence of SPCSV, symptoms in plants co-infected with SPFMV-C and SPCSV were milder compared with plants co-infected with either SPFMV-RC or IVMV and SPCSV. This suggests that enhancement of replication of one virus is not sufficient by itself to induce the severity of symptoms associated with SPVD.

Using TAS-ELISA and RNA hybridization methods, Karyeija et al. (14) found that titers of an East African isolate of SPFMV (Nam 1) were on average 600-fold higher in the presence of SPCSV approximately 5 weeks after inoculation. Realtime RT-PCR quantitative data from this study revealed a much greater increase in titer for the particular SPFMV isolates tested. Mean increases of $10^{4}, 4 \times 10^{4}$, and $3 \times 10^{5}$-fold, obtained by dividing means 
of titer of a virus from mixed and single infection treatments, were observed for SPFMV-RC, SPFMV-C, and SPFMV-95-6, respectively. These findings can be attributed to the more sensitive quantitative capabilities of the real-time RT-PCR assays, and/or the variability, as observed in this study, in the degree of titer enhancement even between strains of the same virus. In pairwise combination with SPCSV, titers of SPFMV-RC, SPFMV-956 , and IVMV peaked between 3 and 6 weeks postinoculation. In contrast, titers of SPFMV-C and SPVG appear to peak at 9 weeks postinoculation. The fact that symptoms were much more severe in mixed infections of the potyviruses with SPCSV compared with single infections with each potyvirus is probably related to the dramatic increase in potyvirus titer in the mixed infections. However, differences in symptom severity caused by different potyviruses in mixed infection with SPCSV are likely due to differences in virulence as each of the potyviruses produced high titers in the presence of SPCSV.

Compared with the potyviruses which were enhanced in the presence of SPCSV, titers of SPCSV were reduced in all treatments involving pairwise infections at both 3 and 6 weeks after inoculation compared to single infections. Our results are very similar to results obtained by both Gibson et al. (9) and Karyeija et al. (14). Karyeija et al. (14) indicated that SPCSV, a phloemlimited virus, remains phloem-limited even when plants are co-infected with SPFMV. Using quantitative real-time RT-PCR, SPCSV was consistently above the threshold of detection compared with any of the potyviruses in single infections, and therefore, a large amount of its viral proteins are probably present throughout the phloem. In pairwise virus combinations with potyviruses, such protein products could be utilized for replication by the individual potyvirus, resulting in the reduction of the efficiency of SPCSV replication and a corresponding increase in the efficiency of potyvirus replication. A similar hypothesis has been postulated by Poolpol and Inouye (23) to explain the reduction of the enhancer virus, Zucchini yellow mosaic virus, in dual infections with Cucumber mosaic virus in cucumber plants.

Titers of SPFMV-RC, IVMV, and SPVG, the commonly occurring potyviruses in the United States, were neither enhanced nor suppressed in pairwise and three-way combinations with each other compared with single infections. These results provide evidence that these viruses do not interact synergistically as determined by titer level, and support the work of Clark and Hoy (7), who found no significant yield losses between virus-tested controls and plants infected with these viruses alone, and only up to $15 \%$ reduction in yield with combinations of these potyviruses.
The importance of the potyvirusencoded helper component proteinase (HC-Pro) in virus replication and accumulation is well documented $(5,15,16,24)$. Involvement in viral RNA amplification also has been suggested for the papain-like leader proteinase (L-Pro) of the closterovi- ruses (21). In fact, both HC-Pro and L-Pro have been grouped in a large class of papain-like leader proteinases that were shown to aid in viral multiplication (8). Additionally, in immature pea embryos infected by the potyvirus Pea seed-borne mosaic virus, the induction of the host's
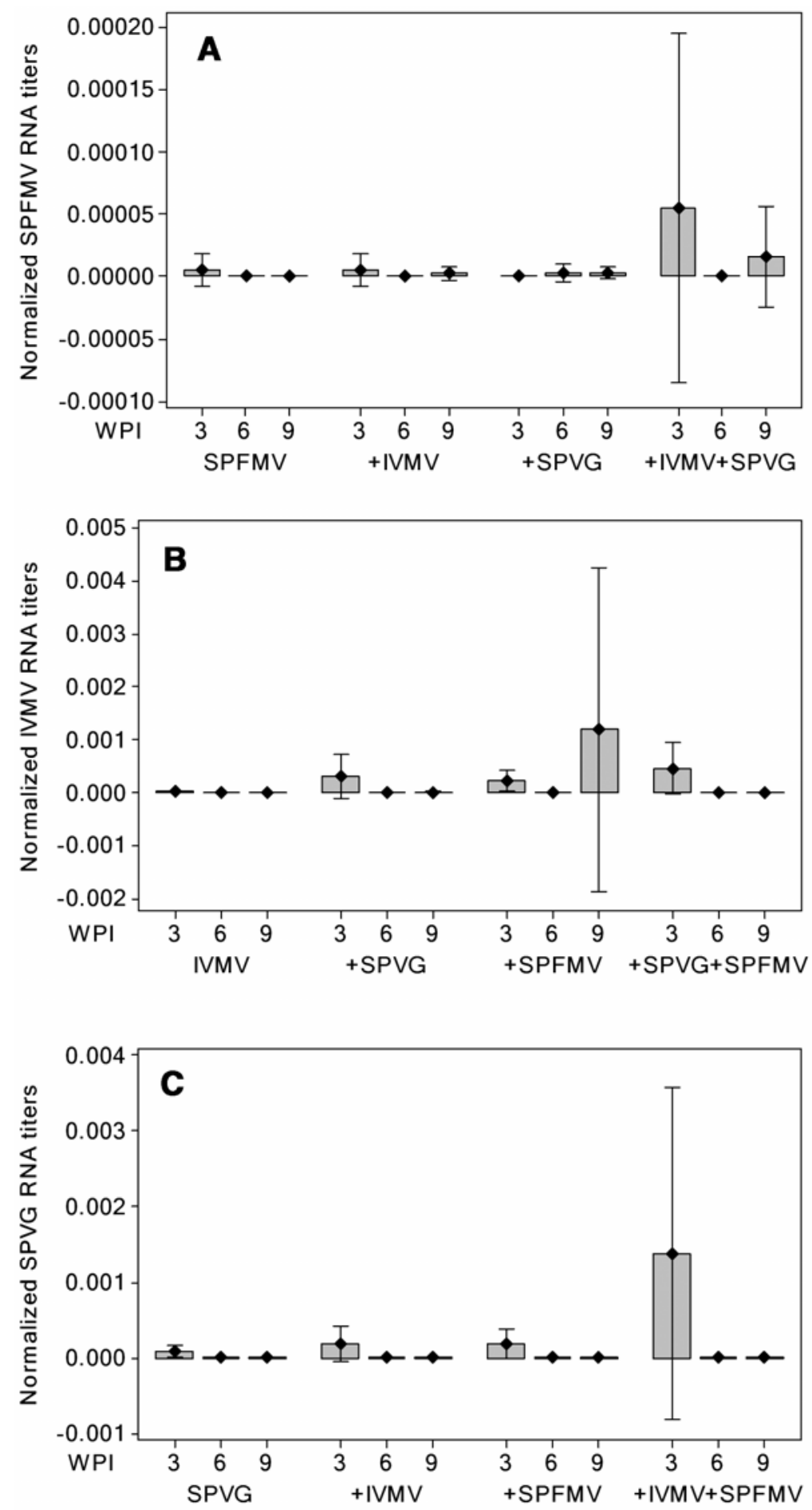

Fig. 4. Mean virus RNA titers, normalized to an endogenous control (18s rRNA) determined by realtime quantitative reverse transcription-polymerase chain reaction (RT-PCR) in single, pairwise, and three-way infections with A, Sweet potato feathery mottle virus (SPFMV), B, Ipomoea vein mosaic virus (IVMV), and C, Sweet potato virus $G$ (SPVG) at 3, 6, and 9 weeks postinoculation (WPI) in six cv. Beauregard sweetpotato plants. Normalized virus RNA titers $(N)$ are derived form the mathematical formula $N=2^{-\Delta \mathrm{Ct}}$, where $\Delta \mathrm{Ct}$ is the difference between the threshold cycles $(\mathrm{Ct})$ of the target virus and endogenous control obtained from their respective real-time amplification plots. Interval bars represent $95 \%$ confidence interval. 
HSP70 gene was associated with virus replication (2). Since closteroviruses also encode a homologue of plant HSP70 (HSP70h), a simple explanation for the titer enhancement of the potyviruses in pairwise virus combinations with SPCSV is that potyviruses may take advantage of protein products encoded by SPCSV, such as L-Pro and HSP70h, for their own replication. Such a mechanism would naturally create a competition between the two viruses, something that in this study may be reflected in the significant reduction of SPCSV titers observed in dual infections.

Since Schaefers and Terry (26) first described SPVD and its viral components, several hypotheses on the mechanism of this synergism have been formulated. To date, however, the exact mechanism of the viral interaction leading to SPVD remains elusive. Regardless of whether or not symptoms were severe, titers of all potyviruses tested here were increased in treatments involving pairwise infections with SPCSV, whereas titers of SPCSV were reduced. These findings suggest two things. The first is that a conserved mechanism probably underlies the enhancement of the potyviruses by SPCSV, and the second is that the act of titer enhancement of a potyvirus may not be sufficient to induce the severity of symptoms associated with SPVD. In a separate study involving cDNA microarrays, most of the sweetpotato genes identified as stress-induced or resistancerelated were differentially expressed in plants affected by SPVD but not in plants infected with either SPFMV or SPCSV alone (C. D. Kokkinos, C. A. Clark, C. E. McGregor, and D. R. LaBonte, unpublished). Considered together with the results of this study, this suggests that the most probable mechanism resulting in the induction of this severe disease is one involving some form of interaction between the two viruses and the host (viral proteinviral protein-host protein interaction) rather than one involving a virus (SPCSV) suppressing the host's defense mechanism so the other virus (SPFMV) can achieve high titers and cause SPVD. The hypothesis of a potyvirus-crinivirushost protein interaction as a basis for disease development and severity is further strengthened by the inability of the potyviruses evaluated in this study to synergistically interact with each other in the absence of SPCSV.

\section{ACKNOWLEDGMENTS}

The authors thank Don LaBonte and Mary Hoy for critically reviewing this manuscript. Financial support of the Louisiana Sweet Potato Advertising and Development Commission and from Coopera- tive Agreement No. 58-6402-4-031 with USDA, ARS, Southern Insect Management Research Unit, Stoneville, MS, are gratefully acknowledged.

\section{LITERATURE CITED}

1. Anjos, J. R., Jarlfors, U., and Ghabrial, S. A. 1992. Soybean mosaic potyvirus enhances the titer of two comoviruses in dually infected soybean plants. Phytopathology 82:1022-1027.

2. Aranda, M. A., Escaler, M., Wang, D., and Maule, A. J. 1996. Induction of HSP70 and polyubiquitin expression associated with plant virus replication. Proc. Natl. Acad. Sci. USA 93:15289-15293.

3. Aritua, V., Adipala, E., Carey, E. E., and Gibson, R. W. 1998. The incidence of sweet potato virus disease and virus resistance of sweet potato grown in Uganda. Ann. Appl. Biol. 132:399-411.

4. Aritua, V., Olanya, O. M., El-Bedewy, R., and Ewell, P. T. 2000. Yield and reaction of nonindigenous sweetpotato clones to sweetpotato virus disease in Uganda. Pages 48-54 in: Proc. Int. Workshop Sweet Potato Cultivar Decline Study. Y. Nakazawa and K. Ishiguro, eds. Miyakonojo, Japan.

5. Atreya, C. D., and Pirone, T. P. 1993. Mutational analysis of the helper componentproteinase gene of a potyvirus: Effects of amino acid substitutions, deletions, and gene replacement on virulence and aphid transmissibility. Proc. Natl. Acad. Sci. USA 90:1191911923.

6. Brunt, A. A., Crabtree, K., Dallwitz, M. J., Gibbs, A. J., and Watson, L. 1996. Viruses of Plants. Descriptions and Lists from the VIDE Database. C.A.B. International, Wallingford, England.

7. Clark, C. A., and Hoy, M. W. 2006. Effects of common viruses on yield and quality of Beauregard sweetpotato in Louisiana. Plant Dis. 90:83-88.

8. Dougherty, W. G., and Semler, B. L. 1993. Expression of virus-encoded proteinases: Functional and structural similarities with cellular enzymes. Microbiol. Rev. 57:781-822.

9. Gibson, R. W., Mpembe, I., Alicai, T., Carey, E. E., Mwanga, R. O. M., Seal, S. E., and Vetten, H. J. 1998. Symptoms, aetiology and serological analysis of sweet potato virus disease in Uganda. Plant Pathol. 47:95-102.

10. Goldberg, K. B., and Brakke, M. K. 1987. Concentration of maize chlorotic mosaic virus increases in mixed infections with maize dwarf mosaic virus strain B. Phytopathology 77:162167.

11. Gutiérrez, D. L., Fuentes, S., and Salazar, L. F. 2003. Sweetpotato Virus Disease (SPVD): Distribution, incidence, and effect on sweetpotato yield in Peru. Plant Dis. 87:297-302.

12. Hahn, S. K. 1976. Effects of viruses (SPVD) on growth and yield of sweet potato. Exp. Agric. 15: 253-256.

13. Karyeija, R. F., Gibson, R. W., and Valkonen, J. P. T. 1998. The significance of sweet potato feathery mottle virus in subsistence sweet potato production in Africa. Plant Dis. 82:4-15.

14. Karyeija, R. F., Kreuze, J. F., Gibson, R. W., and Valkonen, J. P. T. 2000. Synergistic interactions of a potyvirus and a phloem-limited crinivirus in sweetpotato plants. Virology 269:26-36.

15. Kasschau, K. D., and Carrington, J. C. 1995. Requirement for HC-Pro during genome amplification of tobacco etch potyvirus.
Virology 209:268-273.

16. Kasschau, K. D., Cronin, S., and Carrington, J. C. 1997. Genome amplification and longdistance movement functions associated with the central domain of tobacco etch potyvirus helper component-proteinase. Virology 228: 251-262.

17. Kokkinos, C. D., and Clark, C. A. 2006. RealTime PCR assays for detection and quantification of sweetpotato viruses. Plant Dis. 90:783788.

18. Loebenstein, G., and Harpaz, I. 1960. Virus diseases of sweetpotatoes in Israel. Phytopathology 50:100-104.

19. Moyer, J. W., Cali, B. B., and Abu-Ghadir, M. F. 1980. Identification of two sweet potato feathery mottle virus strains found in North Carolina. Plant Dis. 64:762-764.

20. Ngeve, J. M. 1990. Yield stability and yield depression in sweet potato cultivars susceptible to the sweet potato virus disease. J. Hortic. Sci. 65:225-230.

21. Peremyslov, V. V., Hagiwara, Y., and Dolja, V. V. 1998. Genes required for replication of the 15.5-kilobase RNA genome of a plant Closterovirus. J. Virol. 72:5870-5876.

22. Pio-Ribeiro, G., Winter, S., Jarret, R. L., Demski, J. W., and Hamilton, R. I. 1996. Detection of sweet potato virus disease-associated closterovirus in a sweet potato accession in the United States. Plant Dis. 80:551-554.

23. Poolpol, P., and Inouye, T. 1986. Enhancement of cucumber mosaic virus multiplication by zucchini yellow mosaic virus in doubly infected cucumber plants. Ann. Phytopathol. Soc. Jpn. 52:22-30.

24. Pruss, G., Ge, X., Shi, X. M., Carrington, J. C., and Vance, V. B. 1997. Plant viral synergism: The potyviral genome encodes a broad-range pathogenicity enhancer that transactivates replication of heterologous viruses. Plant Cell 9:859-868.

25. Salazar, L. E., and Fuentes, S. 2001. Current knowledge on major virus diseases of sweetpotatoes. Pages 14-19 in: Proc. Int. Workshop Sweetpotato Cultivar Decline study, Sept. 8-9, 2000, Miyakonojo, Japan.

26. Schaefers, G. A., and Terry, E. R. 1976. Insect transmission of sweet potato disease agents in Nigeria. Phytopathology 66:642-645.

27. Sheffield, F. M. L. 1957. Virus diseases of sweet potato in East Africa. Identification of viruses and their insect vectors. Phytopathology 47:582-590.

28. Souto, E. R., Sim, J., Chen, J., Valverde, R. A., and Clark, C. A. 2003. Properties of strains of Sweet potato feathery mottle virus and two newly recognized potyviruses infecting sweet potato in the United States. Plant Dis. 87:12261232.

29. Tairo, F., Kullaya, A., and Valkonen, J. P. T. 2004. Incidence of viruses infecting sweetpotato in Tanzania. Plant Dis. 88:916-920.

30. Valverde, R. A., Lozano, G., Navas-Castillo, J., Ramos, A., and Valdes, F. 2004. First report of Sweet potato chlorotic stunt virus and Sweet potato feathery mottle virus infecting sweet potato in Spain. Plant Dis. 88:428.

31. Vance, V. B. 1991. Replication of potato virus $\mathrm{X}$ RNA is altered in coinfections with potato virus Y. Virology 182:486-494

32. Vance, V. B., Berger, P. H., Carrington, J. C., Hunt, A. G., and Shi, X. M. 1995. 5' proximal potyviral sequences mediate potato virus $\mathrm{X} /$ potyviral synergistic disease in transgenic tobacco. Virology 206:583-590. 